\title{
OPTIMALISASI PEMUNGUTAN PAJAK MINERAL BUKAN LOGAM DAN BATUAN DI KOTA TOMOHON
}

\author{
Christy Virginia Moningka ${ }^{1}$, Hendrik Manossoh ${ }^{2}$, Steven J. Tangkuman ${ }^{3}$ \\ ${ }^{1,2,3}$ Fakultas Ekonomi dan Bisnis, Jurusan Akuntansi, Universitas Sam Ratulangi, Jl.Kampus Bahu, Manado, \\ 95115, Indonesia \\ E-mail : christyvmoningka@gmail.com
}

\begin{abstract}
By the presence of regional autonomy, every region in Indonesia are required to do their own regional financing. Own Source Revenue is a source of regional financial and funding of the government. The Own Source Revenue consists of local taxes, levies, the result of the separated local asset management, and another Own Source Revenue that is valid. In relation to Own Source Revenue, The tax of Non-Metallic Minerals and Rocks is one type of the tax that need to be in government's attention in Tomohon City. The purpose of this research is to know and understand optimization of non-metallic mineral and rock taxes in Tomohon City. The method used in this research is qualitative descriptive analysis. Data gained by field studies. The results of this research indicate that the management of NonMetallic Mineral and Rock taxes in Tomohon City are still not optimal due to tax realization in 2013-2017 has not reached the target that has been determined. The management of NonMetallic Mineral and Rock Taxes that has not been optimal is due to lack of the human resources for tax collection officers, facilities and infrastructure in the office is still inadequate, still lack of supervision from the officers, online information systems that has not been developed and lack of public awareness of the importance of paying taxes.

Keywords : revenue, local taxes, non-metallic mineral and rock taxes, optimization
\end{abstract}

\section{PENDAHULUAN}

Indonesia secara resmi diberlakukan otonomi daerah pada tanggal 1 Januari 2001 yaitu daerah mempunyai wewenang sendiri untuk menjalankan pemerintahannya sendiri sesuai dengan Undang-undang. Dengan diberlakukannya otonomi daerah, maka segala sektor perekonomian dan penyelenggaraan pembiayaan daerah menjadi tanggung jawab daerah itu sendiri, yang sebagian besar diperoleh dari sektor perpajakan. Dalam pelaksanaannya, daerah otonom diharuskan untuk mengoptimalkan penerimaan Pendapatan Asli Daerah untuk membiayai kebutuhan daerahnya sendiri. PAD berasal dari penerimaan pajak daerah, retribusi daerah, pengelolaan kekayaan daerah yang dipisahkan serta lain-lain PAD yang sah. Pajak merupakan salah satu sumber pendapatan terbesar bagi pemerintah yang di dapat dari iuran wajib rakyat kepada negara, dan menurut lembaga yang memungut pajak, pajak terbagi atas pajak pusat dan pajak daerah.

Banyaknya usaha di berbagai bidang di Kota Tomohon memiliki dampak terhadap jumlah penerimaan PAD di Kota Tomohon. Ada beberapa sumber Pendapatan Asli Daerah dan satu diantaranya adalah pajak daerah. Proses pemungutan pajak di Kota Tomohon khususnya pajak daerah masih belum maksimal dikarenakan kurangnya informasi dan pengetahuan mengenai pajak dan masih banyak masyarakat yang kurang menyadari bahwa pentingnya taat membayar pajak. Salah satu pajak daerah yang penerimaannya masih kurang maksimal adalah pajak mineral bukan logam dan batuan. Untuk itu perlu diketahui seberapa besar target dan realisasi pajak terutama pajak Mineral Bukan Logam dan Batuan. Laporan target dan realisasi Pajak Mineral Bukan Logam dan Batuan di Kota Tomohon pada tahun 2013 yaitu target pajak yang diharapkan pemerintah berjumlah Rp 200.000.000 dan hasil 
realisasi pajaknya pada tahun 2013 tidak mencapai target yang sudah ditentukan, hanya berjumlah Rp 69.635.000, yaitu sebesar 34,8\%. Kemudian pada tahun 2014, target yang diharapkan oleh pemerintah yaitu berjumlah $\mathrm{Rp} 450.000 .000$ dan realisasi pajaknya $\mathrm{Rp}$ 394.464.662 yaitu sebesar 87,6\%. Pada tahun 2015, target yang diharapkan pemerintah sebesar Rp 395.000.000 dan realisasi pajaknya sebesar Rp 128.296.775 yaitu sebesar 32,5\% dan tahun 2016, target yang diharapkan oleh pemerintah sebesar Rp 295.000.000 dan realisasi pajaknya sebesar Rp 108.312.912 yaitu sebesar 36,7\%. Pada 2017, target yang ditentukan oleh pemerintah sama dengan tahun sebelumnya yaitu sebesar Rp 295.000.000 dan untuk realisasi pajaknya hanya Rp 132.381 .472 yaitu sebesar 44,9\%. Berdasarkan penjelasan diatas, dapat dilihat bahwa penerimaan Pajak Mineral Bukan Logam dan Batuan di Kota Tomohon pada tahun 2013-2017 belum ada yang mencapai target yang telah ditetapkan oleh pemerintah.

\section{TINJAUAN PUSTAKA}

Pengertian Akuntansi. Akuntansi merupakan suatu sistem yang menghasilkan informasi keuangan untuk mempermudah pihak yang membutuhkan dalam mengambil keputusan. Akuntansi dikenal sebagai suatu disiplin ilmu yang bertujuan untuk menghasilkan informasi ekonomi yang berguna bagi pihak-pihak yang menyelenggarakannya (Sadeli, 2015:5).

Akuntansi Pajak. Akuntansi Pajak menurut Hery (2014:1) adalah suatu sistem yang digunakan untuk menganalisa dan mengatur strategi dalam perencanaan pajak serta perhitungan perpajakan.

\section{Konsep Perpajakan}

Definisi Pajak. Menurut Mardiasmo (2016:1) pajak adalah pungutan terhadap masyarakat untuk Negara yang wajib diberikan dan memaksa berdasarkan peraturan perundangundangan yang digunakan untuk kepentingan umum dan bagi kesejahteraan masyarakat.

Fungsi Pajak. Menurut Waluyo (2013:6), ada dua fungsi pajak yaitu fungsi budgetir yang artinya pajak digunakan untuk membiayai pengeluaran negara yakni kepentingan umum dan fungsi mengatur yang artinya pajak merupakan alat yang digunakan untuk mengatur pertumbuhan ekonomi suatu negara.

Syarat Pemungutan Pajak. Menurut Mardiasmo (2016:4-5) proses pemungutan pajak harus memenuhi syarat yaitu pemungutan harus adil yakni dengan mengenakan pajak secara merata dan sesuai dengan kemampuan dari para wajib pajak, harus berdasarkan undang-undang yakni agar supaya ada jaminan hukum mengenai pemungutan pajak, tidak mengganggu perekonomian yakni dengan tidak mengganggu proses ekonomi negara, harus efisien yakni pendapatan yang masuk ke kas negara harus lebih besar daripada pengeluaran biaya pada saat pemungutan dan harus sederhana agar supaya masyarakat lebih mudah dalam membayar kewajibannya.

Asas Pemungutan Pajak. Dalam Mardiasmo (2016:9) asas-asas pemungutan pajak antara lain: asas domisili (Asas Tempat Tinggal), Asas Sumber, dan Asas Kebangsaan.

Sistem Pemungutan Pajak. Dalam Mardiasmo (2016:9-10) sistem pemungutan pajak antara lain: Official Assessment System, Self Assessment System, dan With Holding System.

Pendapatan Asli Daerah. Pendapatan asli daerah merupakan penerimaan yang didapatkan oleh suatu daerah yang berasal dari sumber-sumber di dalam daerah itu sendiri dan yang sudah ditentukan berdasarkan peraturan perundang-undangan.

Pajak Daerah. Menurut Mardiasmo (2016:12) Pajak Daerah adalah pungutan yang harus dibayar oleh masyarakat pada pihak pemerintah daerah sebagai pengelola yang bersifat memaksa dan sudah diatur dalam peraturan perundang-undangan dan digunakan untuk 
pembangunan daerah serta kesejahteraan masyarakat. Pajak daerah terbagi atas dua yaitu pajak yang dipungut oleh pemerintah provinsi dan pajak yang dipungut oleh pemerintah kabupaten/kota.

\section{Pajak Mineral Bukan Logam dan Batuan}

Pengertian Pajak Mineral Bukan Logam dan Batuan. Pajak Mineral Bukan Logam dan Batuan adalah salah satu dari pajak daerah yang dipungut oleh pemerintah daerah kabupaten/kota. Pajak mineral bukan logam dan batuan menurut UU No. 28 tahun 2009 adalah pajak yang diberikan pada saat terjadinya aktivitas penggalian bahan tambang mineral bukan logam dan batuan dari dalam maupun di permukaan bumi.

Subjek Pajak, Objek Pajak dan Wajib Pajak Mineral Bukan Logam dan Batuan. Orang pribadi atau badan yang mengeksploitasi atau mengambil mineral bukan logam dan batuan subjek pajak dari jenis pajak ini. Sedangkan wajib pajak merupakan orang pribadi atau badan yang menyelenggarakan eksploitasi mineral bukan logam dan batuan. Dalam pajak ini, subjek pajak (yang dikenakan pajak/ yang menanggung beban pajak) sama dengan wajib pajak (yang diwajibkan untuk melakukan pembayaran pajak yang terutang). Objek Pajaknya adalah asbes, bentonit, gips, marmer, perlit, tawas, batu tulis, dolomit, kalsit, nitrat, phospat, tras, batu setengah permata, feldspar, kaolin, opsiden, talk, yarosif, batu kapur, garam dan batu (halite), leusit, oker, tanah serap, zeolit, batu apung, grafit, magnesit, pasir dan kerikil, tanah diatome, basal, batu permata, granit/andesit, mika, pasir kuarsa, tanah liat, traktit dan mineral bukan logam dan batuan lainnya sesuai dengan ketentuan perundang-undangan.

Optimalisasi. Optimal memiliki arti yaitu sebagai sesuatu yang sangat baik, sangat tinggi dan sesuatu yang sangat maksimal. Begitu juga dengan kata mengoptimalkan memiliki arti yaitu membuat sesuatu menjadi lebih baik dari sebelumnya, lebih tinggi dari sebelumnya. Sedangkan optimum adalah kondisi yang menunjukkan suatu hal dalam keadaan yang terbaik dan yang paling menguntungkan.

Intensifikasi Pajak dan Ekstensifikasi Pajak. Menurut Surat Edaran Direktorat Jendral Pajak No.SE-06/PJ/9/2001 Intensifikasi pajak adalah suatu upaya untuk memaksimalkan perolehan pajak dari objek dan subjek ada dalam daftar administrasi Dirjen Pajak serta dari hasil pelaksanaan ekstensifikasi wajib pajak. Sedangkan untuk ekstensifikasi pajak adalah suatu upaya yang berhubungan dengan menambahkan jumlah wajib pajak dan objek pajak yang ada dalam administrasi Dirjen Pajak.

Penelitian Terdahulu. Toti Indrawati (2013) dengan judul Analisis Kontribusi Pajak Mineral Bukan Logam Dan Batuan terhadap Pendapatan Asli Daerah Kabupaten Rokan Hulu Tahun 2007 - 2012. Tujuan Penelitian menganalisis kontribusi Pajak Mineral Bukan Logam Dan Batuan terhadap PAD dalam kurun waktu 5 tahun yaitu 2007 - 2012. Metode yang digunakan kualitatif dan kuantitatif. Hasil penelitian selama kurun waktu 5 tahun kontribusi Pajak Mineral Bukan Logam Dan Batuan terhadap PAD sangat kurangnya kontribusi Pajak Mineral Bukan Logam Dan Batuan disebabkan karena pemerintah kabupaten rokan hulu hanya mengelola 1 sumber mineral saja. Hendra Darmayanto (2013) dengan judul Analisis Strategi Peningkatan Pendapatan Pajak Mineral Bukan Logam dan Batuan di Kota Bima. Tujuan penelitian mengetahui strategi apa yang bisa dijalankan guna mendapatkan hasil yang optimal dalam pengelolaan pajak mineral bukan logam dan batuan di wilayah Kota Bima. Metode penelitian kuantitatif. Hasil Penelitian terdapat 12 alternatif strategi yang bisa dijalankan oleh DPPKAD untuk mengoptimalkan pengelolaan pajak mineral bukan logam dan batuan di Kota Bima. Mohammad Afandy (2013) dengan judul Strategi Dinas Pendapatan Daerah dalam Meningkatkan Pendapatan Asli Daerah dari Pajak Daerah di Kabupaten Penajam Paser Utara. Tujuan penelitian untuk mengetahui strategi dinas pendapatan daerah dalam meningkatkan PAD dari pajak daerah. Metode penelitian kualitatif. 
Hasil penelitian strategi Dispenda dalam meningkatkan PAD melalui intensifikasi dan ekstensifikasi, namun intensifikasi yang dilakukan Dispenda tidak dapat meningkatkan PAD sedangkan ekstensifikasi yang ada dapat meningkatkan Pajak Daerah Kabupaten Penajam Paser Utara.

\section{METODE PENELITIAN}

Jenis Penelitian. Jenis penelitian yang digunakan adalah penelitian kualitatif. Penelitian kualitatif merupakan penelitian terhadap masalah-masalah berupa fakta-fakta saat ini dari suatu populasi (Indriantoro \& Supomo, 2013:26). Penelitian ini berhubungan dengan pendapat, persepsi atau opini dari suatu kelompok/individu mengenai masalah yang akan diteliti.

Tempat dan Waktu Penelitan. Penelitian dilakukan pada Badan Keuangan Daerah (BKD) Kota Tomohon. Waktu penelitian ini dilaksanakan pada bulan April 2018.

\section{Metode Pengumpulan Data}

Jenis Data. Peneliti menggunakan jenis data kualitatif melalui wawancara terhadap narasumber dari pihak instansi terkait yaitu Badan Keuangan Daerah Kota Tomohon.

Sumber Data. Dalam penelitian ini, sumber data peneliti yaitu berasal dari:

1. Data primer berupa hasil wawancara dengan pihak Badan Keuangan Daerah Kota Tomohon.

2. Data sekunder berupa data mengenai target dan realisasi pajak daerah Kota Tomohon tahun 2013-2017, laporan realisasi APBD Kota Tomohon tahun 2013-2017, Peraturan Daerah Kota Tomohon No. 7 tahun 2012 tentang pajak daerah, Perwako Tomohon No. 43 tahun 2012 tentang sistem, prosedur dan sanksi pemungutan pajak daerah Kota Tomohon.

Teknik Pengumpulan Data. Teknik pengumpulan data yang digunakan dalam penelitian ini yaitu wawancara, dan dokumentasi.

Metode analisis. Metode yang digunakan untuk membahas permasalahan dalam penelitian ini adalah metode analisis deskriptif kualitatif yaitu untuk menguraikan secara detail mengenai Optimalisasi Pemungutan Pajak Mineral Bukan Logam dan Batuan. Dalam penelitian ini, untuk lebih memahami dan mengetahui tentang optimalisasi pajak ini, peneliti menggunakan beberapa indikator seperti intensifikasi pajak dan ekstensifikasi pajak.

\section{HASIL PENELITIAN DAN PEMBAHASAN}

\subsection{Hasil Penelitian}

Badan Keuangan Daerah (BKD) merupakan Instansi Pemerintah yang didirikan bersama dengan adanya pemerintah daerah yang pelaksanaannya diatur dengan UndangUndang Nomor 10 tahun 2003 tanggal 27 Januari 2003. Pada tahun 2005 Kota Tomohon diberikan wewenang untuk mengurus dan memajukan daerah sendiri berdasarkan peraturan perundang-undangan dan sudah mengalami beberapa perubahan nama sampai saat ini. Dari penelitian yang peneliti lakukan di Badan Keuangan Daerah (BKD) Kota Tomohon, peneliti memperoleh data-data sebagai berikut.

Tabel 1. Rekapitulasi APBD Kota Tomohon Tahun 2013 - 2017

\begin{tabular}{cccc}
\hline Tahun & Target (RP) & Realisasi (Rp) & Presentase \\
\hline 2013 & 945.659 .624 .205 & 912.714 .722 .606 & $96 \%$ \\
2014 & 1.110 .550 .663 .609 & 1.042 .605 .575 .841 & $94 \%$ \\
2015 & $1,193,065,398,189$ & 1.109 .180 .534 .980 & $93 \%$ \\
2016 & $1,390,237,492,442$ & 1.276 .567 .497 .023 & $92 \%$ \\
2017 & $1,357,492,155,634$ & 1.281 .825 .926 .012 & $94 \%$
\end{tabular}

Sumber : Badan Keuangan Daerah Kota Tomohan, 2018 (diolah) 
Tabel 2. Kontribusi PAD terhadap APBD Kota Tomohon Tahun 2013 - 2017

\begin{tabular}{cccc}
\hline Tahun & PAD & APBD & Presentase \\
\hline 2013 & 13.945 .339 .275 & 912.714 .722 .606 & $1.5 \%$ \\
2014 & 16.486 .431 .368 & 1.042 .605 .575 .841 & $1.6 \%$ \\
2015 & 20.100 .568 .636 & 1.109 .180 .534 .980 & $1.8 \%$ \\
2016 & 26.011 .141 .966 & 1.276 .567 .497 .023 & $2.0 \%$ \\
2017 & 34.179 .041 .704 & 1.281 .825 .926 .012 & $2.7 \%$ \\
\hline
\end{tabular}

Sumber : Badan Keuangan Daerah Kota Tomohan, 2018 (diolah)

Tabel 3. Rekapitulasi Target dan Realisasi Pajak MBLB Kota Tomohon

Tahun $2013-2017$

\begin{tabular}{ccccc}
\hline No & Tahun & Target & Realisasi & Presentase \\
\hline 1 & 2013 & 200.000 .000 & 69.635 .000 & $34,8 \%$ \\
2 & 2014 & 450.000 .000 & 394.464 .662 & $87,6 \%$ \\
3 & 2015 & 395.000 .000 & 128.296 .775 & $32,5 \%$ \\
4 & 2016 & 295.000 .000 & 108.312 .912 & $36,7 \%$ \\
5 & 2017 & 295.000 .000 & 132.381 .472 & $44,8 \%$ \\
\hline
\end{tabular}

Sumber : Badan Keuangan Daerah Kota Tomohon, 2018 (diolah)

Tabel 4. Sumbangsih Pajak MBLB ke Pajak Daerah Kota Tomohon Tahun 2013 -2017

\begin{tabular}{ccccc}
\hline No. & Tahun & MBLB & Pajak Daerah & Presentase \\
\hline 1 & 2013 & 69.635 .000 & 5.458 .559 .604 & $1,2 \%$ \\
2 & 2014 & 394.464 .662 & 9.756 .925 .375 & $4 \%$ \\
3 & 2015 & 128.296 .775 & 10.637 .396 .788 & $1,2 \%$ \\
4 & 2016 & 108.312 .912 & 12.435 .848 .866 & $0,9 \%$ \\
5 & 2017 & 132.381 .472 & 16.045 .169 .432 & $0,8 \%$ \\
\hline
\end{tabular}

Sumber : Badan Keuangan Daerah Kota Tomohon, 2018 (diolah)

Tabel 5. Sumbangsih Pajak MBLB ke PAD Kota Tomohon Tahun 2013 -2017

\begin{tabular}{ccccc}
\hline No. & Tahun & PAD & MBLB & Presentase \\
\hline 1 & 2013 & 13.945 .339 .275 & 69.635 .000 & $0,5 \%$ \\
2 & 2014 & 16.486 .431 .368 & 394.464 .662 & $2,4 \%$ \\
3 & 2015 & 20.100 .568 .636 & 128.296 .775 & $0,6 \%$ \\
4 & 2016 & 26.011 .141 .966 & 108.312 .912 & $0,4 \%$ \\
5 & 2017 & 34.179 .041 .704 & 132.381 .472 & $0,4 \%$ \\
\hline
\end{tabular}

Sumber : Badan Keuangan Daerah Kota Tomohon, 2018 (diolah)

\subsection{Pembahasan}

Dari data yang peneliti dapatkan, penerimaan PAD di Kota Tomohon dari pajak mineral bukan logam dan batuan masih belum maksimal, oleh karena itu diperlukan suatu upaya dari pemerintah daerah untuk mengoptimalisasikan pemungutan pajak mineral bukan logam dan batuan di Kota Tomohon. Upaya-upaya tersebut dapat dilakukan melalui intensifikasi pajak dan ekstensifikasi pajak.

Intensifikasi Pajak. Menurut Surat Edaran Direktorat Jendral Pajak No.SE06/PJ/9/2001, Intensifikasi pajak adalah suatu upaya untuk memaksimalkan perolehan pajak dari objek dan subjek ada dalam daftar administrasi Dirjen Pajak serta dari hasil pelaksanaan ekstensifikasi wajib pajak, sedangkan Afandy (2013) menyatakan intensifikasi adalah upaya yang dilakukan untuk membuat penambahan terhadap penerimaan pajak dengan mengatur sumber penerimaan pajak yang sudah ada lebih baik lagi. Sejalan dengan pengertian intensifikasi yang dinyatakan berdasarkan surat edaran Direktur Jendral Pajak diatas, maka 
untuk mengoptimalkan penerimaan pajak daerah khususnya pajak mineral bukan logam dan batuan di Kota Tomohon peneliti menggunakan 5 indikator. Kelima indikator ini digunakan untuk menjelaskan upaya-upaya intensifikasi pajak yang dilakukan Badan Keuangan Daerah Kota Tomohon untuk mengoptimalkan pemungutan pajak mineral bukan logam dan batuan di Kota Tomohon. Kelima indikator tersebut yaitu sistem dan prosedur pemungutan pajak, petugas pemungutan pajak, sarana dan prasarana, pengawasan dan regulasi.

1. Sistem dan Prosedur. Sistem dan prosedur pemungutan pajak daerah mencakup seluruh rangkaian proses yang harus dilakukan oleh wajib pajak berkaitan dengan pendataan dan perhitungan, pelaporan dan penetapan serta pembayaran/ penyetoran pajak terutang. Sistem yang dimaksud di atas adalah tata cara pemungutan pajak seperti yang tercantum pada pasal 2 Perda Kota Tomohon No 7 Tahun 2012. Untuk Pajak Mineral bukan Logam dan Batuan diberlakukan Self Assessment System yaitu jenis pajak yang dihitung dan dibayarkan sendiri oleh wajib pajak. Sistem dan prosedur yang digunakan dalam proses pembayaran pajak daerah di Kota Tomohon terlebih untuk Pajak Mineral bukan Logam dan Batuan sangatlah mudah. Pihak Badan Keuangan Daerah terlebih dari bidang pajak dan retribusi sendiri sudah memberikan kemudahan kepada masyarakat khususnya wajib pajak Kota Tomohon untuk membayar/ menyetor pajak. Seperti yang di katakan Ibu Vonny selaku kepala bidang pajak dan retribusi Badan Keuangan Daerah Kota Tomohon dalam wawancara:

"Untuk proses pemungutan pajak mineral bukan logam dan batuan yang dilaksanakan oleh BKD di Kota Tomohon sendiri ada beberapa cara. Yang pertama yaitu wajib pajak menyetorkan sendiri secara langsung pajak terutang yang telah dihitung di kantor BKD. Yang kedua petugas pemungut pajak kami melakukan penagihan secara langsung dan yang ketiga yaitu melakukan penagihan melalui kontraktor-kontraktor. Tanggal penagihan biasanya dilakukan setiap awal bulan setelah bulan masa pajak berakhir atau paling lambat tanggal 7 setelah berakhirnya bulan masa pajak."

Selain yang sudah dijelaskan di atas, sistem dan prosedur juga mencakup sanksi pemungutan pajak jika wajib pajak tidak membayar/menyetorkan pajak terutang tepat pada waktunya. Seperti yang di jelaskan Ibu Vonny sebagai berikut:

"Untuk sanksi pastinya ada, tergantung pada seberapa lama wajib pajak terlambat membayar pajaknya. Jika wajib pajak tidak membayar pajak pada waktu yang sudah ditentukan maka wajib pajak akan mendapatkan surat peringatan/surat teguran pertama dan akan diberikan denda sebesar 2\%. Jika satu minggu sesudahnya wajib pajak masih belum membayar pajaknya beserta denda $2 \%$ yang sudah diberikan, maka akan diberikan surat peringatan/surat teguran kedua. Jika pada minggu berikutnya wajib pajak masih belum juga membayar pajak maka akan diberikan peringatan terakhir oleh Polisi Pamong Praja. Kemudian jika sudah diberikan peringatan terakhir dan masih belum membayar maka polisi pamong praja akan menutup sementara kegiatan usaha tersebut. Satu minggu sesudahnya dan masih belum membayar maka akan diserahkan pada aparat hukum untuk diproses lebih lanjut."

Berdasarkan penjelasan diatas, sistem dan prosedur yang dilakukan Badan Keuangan Daerah Kota Tomohon sudah baik karena Badan Keuangan Daerah Kota Tomohon sudah menjalankan sistem dan prosedur yang ada sesuai dengan peraturan yang berlaku serta memberlakukan sanksi terhadap para wajib pajak yang tidak taat dalam membayar pajak.

2. Petugas Pemungutan Pajak. Petugas di Badan Keuangan Daerah adalah orang-orang yang sudah ditetapkan berdasarkan surat keputusan pejabat yang berwenang untuk melakukan penagihan/ pemungutan terhadap pajak. Badan Keuangan Daerah Kota Tomohon sendiri memiliki sumber daya manusia yang bertugas khusus dalam bidang penagihan pajak. Dalam wawancara, Bapak Audi sebagai salah satu staf di bidang pajak dan retribusi Badan Keuangan Daerah menyatakan bahwa: 
"Yang bertugas untuk menagih pajak di Badan Keuangan Daerah Kota Tomohon ada sekitar 10 orang. 3 orang petugas perempuan dan 7 orang petugas laki-laki. Kalau untuk menagih semua jenis pajak daerah, 10 orang ini tidak akan cukup. Dengan jumlah yang bisa dibilang sedikit ini pihak kami masih mengalami kesulitan karena kurangnya sumber daya manusia."

Dilihat dari hasil wawancara, Badan Keuangan Daerah Kota Tomohon masih sangat membutuhkan sumber daya manusia sebagai petugas pemungut pajak karena 10 orang yang bertugas sebagai pemungut pajak ini masih dianggap sangat kurang untuk semua jenis pajak daerah di Kota Tomohon.

3. Sarana dan prasarana. Sarana dan prasarana adalah faktor yang penting untuk mendukung kelancaran proses pemungutan pajak. Dengan sarana dan prasarana yang baik maka dapat memudahkan dan mempercepat para petugas serta para wajib pajak untuk melakukan kegiatan mereka dalam proses pemungutan pajak sebagai petugas pemungut pajak dan wajib pajak. Bapak Audi dalam wawancara menjelaskan bahwa:

"Badan Keuangan Daerah Kota Tomohon sudah menyiapkan sarana dan prasarana untuk membantu kelancaran proses pemungutan pajak di Kota Tomohon. Sarana dan prasarana yang telah disiapkan oleh Badan Keuangan Daerah Kota Tomohon ada 4 mobil dan 10 motor yang terdiri dari kendaraan dinas dan kendaraan pribadi. Selain itu, sarana dan prasarana di kantor kami sendiri dapat dikatakan masih kurang maksimal untuk proses pembayaran semua jenis pajak daerah yang ada di Kota Tomohon, seperti loket untuk pembayaran, tempat untuk menuliskan formulir, kursi yang digunakan masyarakat saat ingin membayar pajak, dan sebagainya."

Dilihat dari hasil wawancara di atas, Badan Keuangan Daerah Kota Tomohon masih memerlukan pengembangan terhadap sarana dan prasarana terlebih untuk yang ada di kantor agar supaya masyarakat sebagai wajib pajak lebih merasa nyaman dan dimudahkan dengan adanya sarana dan prasarana yang memadai.

4. Pengawasan. Pengawasan merupakan sesuatu yang penting yang dilakukan untuk mengontrol proses serta kegiatan yang dilaksanakan apakah sudah sesuai dengan aturan yang berlaku atau tidak. Ibu Vonny dalam wawancaranya menjelaskan bahwa:

"Pengawasan yang kami lakukan yaitu dengan cara membuat portal di lokasi penambangan untuk mengontrol volume/tonase hasil tambang, memberikan pemahaman kepada kontraktor-kontraktor serta pembeli mengenai pembayaran pajak mineral bukan logam dan batuan, selalu memberitahukan tentang update harga standar nilai jual serta dengan melihat laporan-laporan yang berhubungan dengan kegiatan penambangan tersebut."

Badan Keuangan Daerah Kota Tomohon dalam hal ini dapat dikatakan sudah melakukan tugas pengawasan dengan baik terhadap proses-proses atau kegiatan penambangan yang dilakukan di Kota Tomohon.

5. Regulasi. Regulasi merupakan peraturan-peraturan yang mendasari proses pemungutan pajak mineral bukan logam dan batuan, baik peraturan yang berasal dari pusat maupun peraturan yang berasal dari daerah. Bapak Djon menjelaskan bahwa:

"Tentu saja BKD dalam melaksanakan tugas pemungutan pajak daerah memiliki dasar hukum dan regulasi yang dijadikan sebagai acuan. Untuk peraturan yang berasal dari pemerintah pusat, kami mengacu pada Undang-Undang Nomor 28 Tahun 2009 tentang Pajak Daerah dan Retribusi Daerah, sedangkan peraturan yang berasal dari pemerintah daerah Kota Tomohon yaitu Peraturan Daerah Kota Tomohon Nomor 7 Tahun 2012 tentang Pajak Daerah. Selain itu, ada juga peraturan yang diberikan dari pemerintah daerah yaitu Peraturan Walikota Tomohon Nomor 43 Tahun 2012 tentang Sistem, Prosedur dan Sanksi Pemungutan Pajak Daerah Kota Tomohon."

Dari hasil wawancara di atas, sudah dapat disimpulkan bahwa Badan Keuangan Daerah 
sudah melakukan hal ini dengan baik. Badan Keuangan Daerah selalu menjalankan tugas berdasarkan peraturan yang berlaku.

Ekstensifikasi Pajak. Upaya peningkatan pendapatan asli daerah dari segi pajak khususnya pajak mineral bukan logam dan batuan juga dapat dilakukan dengan cara ekstensifikasi. Menurut Surat Edaran Direktur Jendral Pajak No.SE-06/PJ.9/2001 Ekstensifikasi Pajak adalah upaya untuk memperbanyak jumlah wajib pajak dan objek pajak yang baru di dalam administrasi Dirjen Pajak. Sehubungan dengan pengertian ekstensifikasi yang dinyatakan dalam surat edaran Direktur Jendral Pajak diatas, maka untuk menambahkan wajib pajak terdaftar dan perluasan objek pajak dalam administrasi DJP peneliti menggunakan dua indikator. Kedua indikator ini digunakan untuk menjelaskan upaya-upaya ekstensifikasi yang dilakukan oleh Badan Keuangan Daerah untuk mengoptimalkan penerimaan pajak ini di Kota Tomohon. Kedua indikator tersebut adalah dengan mengadakan sosialisasi dan penyuluhan, serta membentuk tim pemeriksa pajak. Sosialisasi Wajib Pajak sangatlah dibutuhkan untuk memberikan ilmu kepada masyarakat yang belum mengerti tentang pajak. Oleh sebab itu sosialisasi dan penyuluhan merupakan salah satu faktor yang penting dalam mengoptimalkan pemungutan pajak.

Ibu Vonny dalam wawancaranya menyatakan bahwa: "Kami dari pihak pemungut pajak dalam hal ini Badan Keuangan Daerah Kota Tomohon melakukan sosialisasi dan penyuluhan kepada masyarakat yang masih belum paham tentang pajak. Biasanya dilakukan 3 bulan sekali di kantor kelurahan bersamaan dengan rapat kelurahan dan dilaksanakan sekaligus untuk semua wajib pajak yang ada di Kota Tomohon mengenai sistem dan prosedur, tarif dan cara perhitungan pajak, cara pembayaran/ penyetoran pajak, dan lainlain." Selain itu masyarakat juga membutuhkan sosialisasi dalam bentuk iklan-iklan yang dapat dilihat dan didengar dimana saja. Bapak Audi dalam wawancaranya menjelaskan bahwa: "Selain sosialisasi dan penyuluhan yang kami buat di kelurahan, tentu saja kami membuat sosialisasi dalam bentuk pemasangan iklan seperti pembuatan stiker-stiker, baliho dan sebagainya, serta iklan berupa pengumuman di radio untuk pembayaran pajak dan informasi lain tentang pajak di Kota Tomohon agar supaya masyarakat Kota Tomohon lebih mengenal dan mengetahui informasi tentang pajak."

Berdasarkan pernyataan di atas, sosialisasi dan penyuluhan yang diberikan oleh pemerintah ini dilakukan dengan harapan para masyarakat yang berada di Kota Tomohon yang memiliki usaha dan harus membayar pajak bisa sadar akan pentingnya membayar pajak. Selain dengan sosialisasi dan penyuluhan, dibentuklah tim pemeriksa pajak oleh pihak Badan Keuangan Daerah. Bapak Friedel dalam wawancaranya menjelaskan bahwa:

"Saat ini kami dari pihak BKD sedang membentuk tim pemeriksa pajak untuk melakukan pemeriksaan terhadap wajib pajak yang tidak taat membayar pajak dan yang belum sadar untuk membayar pajak, serta kami sudah bekerja sama dengan pihak kelurahan, kecamatan bahkan dengan kepolisian untuk menangani masalah ini. Selain itu, kami juga sudah bekerja sama dan menyerahkan data-data pada pihak KPK untuk menyelidiki dan menyelesaikan permasalahan Pajak Mineral Bukan Logam dan Batuan di Kota Tomohon."

Bapak Friedel juga menambahkan dalam wawancaranya bahwa:

"Kendalanya yaitu banyak yang belum sadar untuk membayar pajak, sedangkan penerimaan Pajak Mineral Bukan Logam dan Batuan per bulan sangat besar. Untuk 1 kubik yang dimuat dalam satu mobil truk bisa dihitung kurang lebih sekitar 40-50 juta. Kendala yang ada juga kami sangat kesulitan dalam melakukan penagihan terhadap tambang-tambang rakyat atau tambang-tambang kecil karena terhambat dari segi keamanan untuk para petugas pemungutnya. Oleh sebab itu kami memutuskan untuk bekerja sama dengan pihak kelurahan, kecamatan, kepolisian serta KPK."

Dalam penjelasan Bapak Friedel dijelaskan bahwa sangat kesulitan untuk melakukan penagihan terhadap tambang-tambang kecil yang ada di Kota Tomohon yang belum sadar 
akan pentingnya membayar pajak. Oleh sebab itu pihak Badan Keuangan Daerah sudah mengupayakan dengan bekerja sama dengan pihak kelurahan, kecamatan bahkan dengan kepolisian dan KPK untuk menangani kasus ini. Selain itu, Bapak Djon juga dalam wawancaranya menjelaskan bahwa:

"Sejak dikeluarkannya UU No. 23 Tahun 2014 tentang Pemerintahan Daerah, semua kegiatan yang menyangkut pertambangan diambil alih oleh Provinsi. Kami dari pihak BKD hanya bertugas untuk memungut pajak mineral bukan logam dan batuan."

Ibu Vonny juga menjelaskan bahwa:

"Semua kegiatan dalam pertambangan termasuk pengurusan izin dan lain-lain dilakukan oleh pemerintah Provinsi Sulawesi Utara sedangkan tugas kami dari pihak BKD selaku pemerintah Kota Tomohon hanya melakukan pemungutan pajak dalam hal ini pajak mineral bukan logam dan batuan."

Dari penjelasan di atas dapat kita simpulkan bahwa untuk segala jenis kegiatan pertambangan, Pemerintah Daerah dalam hal ini pemerintah Kota Tomohon hanya memiliki wewenang dalam proses pemungutan pajak mineral bukan logam dan batuan, sedangkan untuk proses perizinan dan lain-lain dilaksanakan oleh pemerintah Provinsi Sulawesi Utara.

\section{KESIMPULAN DAN SARAN}

\subsection{Kesimpulan}

Berdasarkan penelitian yang telah dilakukan pada Badan Keuangan Daerah Kota Tomohon, maka diperoleh kesimpulan sebagai berikut:

1. Intensifikasi Pajak. Dalam penelitian, peneliti menggunakan 5 indikator untuk upayaupaya intensifikasi pajak dari Badan Keuangan Daerah Kota Tomohon, yaitu:

a. Sistem dan Prosedur yang baik dan sederhana yang memudahkan para masyarakat dalam proses pembayaran pajak serta memberlakukan sanksi kepada para wajib pajak yang tidak taat dalam membayar pajak.

b. Jumlah sumber daya manusia yang bertugas sebagai petugas pemungut pajak yang masih kurang dapat mempengaruhi proses penagihan pajak serta peningkatan penerimaan pajak di Kota Tomohon.

c. Sarana dan prasarana yang memadai dari segi kendaraan untuk proses pemungutan pajak sendiri sudah maksimal tetapi untuk sarana dan prasarana untuk di dalam kantor sendiri masih belum maksimal karena jumlah dan pengadaanya masih kurang.

d. Pengawasan yang telah dilakukan oleh pemerintah Kota Tomohon yakni Badan Keuangan Daerah Kota Tomohon terhadap proses atau kegiatan penambangan dilakukan dengan cukup baik.

e. Regulasi yang mendasari proses pemungutan pajak daerah di Kota Tomohon oleh pemerintah pusat yaitu UU Nomor 28 Tahun 2009 serta regulasi oleh pemerintah daerah yaitu Perda Kota Tomohon Nomor 7 Tahun 2012 tentang Pajak Daerah. Selain itu, ada juga peraturan yang diberikan dari pemerintah daerah yaitu Perwako Tomohon Nomor 43 Tahun 2012 tentang Sistem, Prosedur dan Sanksi Pemungutan Pajak Daerah Kota Tomohon.

2. Ekstensifikasi Pajak. Dari segi ekstensifikasi pajak, upaya-upaya yang dilakukan oleh pemerintah Kota Tomohon adalah mengadakan sosialisasi dan penyuluhan serta dengan pembentukan tim pemeriksa pajak. Sosialisasi dan Penyuluhan yang dilakukan oleh Pemerintah Kota Tomohon sudah dilakukan dengan baik yaitu dengan cara dilakukan penyuluhan di kantor kelurahan setiap 3 bulan sekali, sosialisasi dengan pengadaan stikerstiker dan baliho serta iklan berupa pengumuman di radio mengenai informasi tentang pembayaran pajak dan sebagainya, serta dibentuk tim pemeriksa pajak untuk melakukan pemeriksaan terhadap wajib pajak yang tidak taat dengan bekerja sama dengan pihakpihak yang berwenang seperti kelurahan, kecamatan, kepolisian serta KPK. Selain itu 
berdasarkan peraturan perundang-undangan semua kegiatan yang berkaitan dengan pertambangan akan langsung diurus oleh Provinsi. Pihak Badan Keuangan Daerah hanya melakukan sesuai dengan tugas mereka yaitu melakukan pemungutan pajak pada para wajib pajak.

\subsection{Saran}

1. Dilakukan pengembangan terhadap sistem informasi online pajak daerah agar masyarakat bisa lebih mudah dalam mendapatkan informasi mengenai pajak serta lebih mudah dalam membayar pajak.

2. Sumber daya manusia yang kurang sebaiknya diadakan penambahan agar supaya proses pemungutan pajak berjalan dengan baik dan penagihan bisa dioptimalkan.

3. Dilakukan pengadaan sarana dan prasarana untuk di kantor untuk kenyamanan dan kelancaran dalam proses pembayaran/penyetoran pajak yang dilakukan di kantor.

4. Peningkatan pengawasan terhadap pelaksanaan pemungutan penerimaan pajak daerah serta peningkatan koordinasi antar unit satuan kerja terkait agar penerimaan yang bersumber dari pajak daerah dapat tercapai secara optimal.

\section{DAFTAR PUSTAKA}

Afandy, Mohammad. 2013. Strategi Dinas Pendapatan Daerah dalam Meningkatkan Pendapatan Asli Daerah dari Pajak Daerah di Kabupaten Penajam Paser Utara. Ejournal Program Ilmu Pemerintahan Fisip Universitas Mulawarman.

Darmayanto, Hendra. 2014. Analisis Strategi Peningkatan Pendapatan Pajak Mineral Bukan Logam dan Batuan di Kota Bima. Jurnal Ekonomi Universitas Terbuka Jakarta.

Direktorat Jendral Pajak. 2001. Surat Edaran Direktur Jendral Pajak Nomor SE-06/PJ.9/2001

Tentang Pelaksanaan Ekstensifikasi Pajak dan Intensifikasi Pajak.

Hery, 2014. Akuntansi Perpajakan. PT Grasindo, Jakarta.

Indrawati, Toti. 2013. Analisis Kontribusi Pajak Mineral Bukan Logam Dan Batuan terhadap

Pendapatan Asli Daerah Kabupaten Rokan Hulu Tahun 2007-2012. Jurnal Ekonomi

Universitas Riau.

Indriantoro, Nur dan Supomo, Bambang, 2013. Metodologi Penelitian Bisnis untuk Akuntansi \& Manajemen. Yogyakarta: BPFE.

Mardiasmo, 2016. Perpajakan. Edisi Terbaru 2016. Andi. Yogyakarta.

Peraturan Daerah. 2012. Peraturan Daerah Kota Tomohon No. 7 Tahun 2012 tentang Pajak

Daerah Kota Tomohon.

Peraturan Walikota. 2012. Peraturan Walikota Kota Tomohon No. 43 Tahun 2012 tentang

Sistem Prosedur dan Sanksi Pemungutan Pajak Daerah Kota Tomohon.

Republik Indonesia. 2004. Undang-undang tentang pemerintahan daerah. Undang-undang No. 32 tahun 2004.

Republik Indonesia. 2008. Undang-undang tentang Pajak Penghasilan. Undang-undang No. 36 Tahun 2008.

Republik Indonesia. 2009. Undang-undang tentang Pajak Daerah dan Retribusi Daerah. Undang-undang No. 28 Tahun 2009.

Sadeli. 2015. Dasar-Dasar Akuntansi. Bumi Aksara, Jakarta.

Samudra, Azhari Aziz. 2015. Perpajakan di Indonesia: Keuangan, Pajak dan Retribusi Daerah. Rajawali Pers, Jakarta.

Waluyo, 2013. Perpajakan Indonesia. Salemba Empat, Jakarta. 